\title{
nature
}

12 August 2004 Volume 430 Issue no 7001

\section{Fear and loathing at Los Alamos}

The laboratory that gave birth to the nuclear bomb is caught in an unsettling downward spiral of weak leadership and dwindling staff morale.

$\mathrm{T}$ he plagues afflicting Los Alamos National Laboratory in New Mexico are beginning to reach Biblical proportions. Since 1999, when the lab became the target of a so-far inconclusive probe into the apparent leaking of warhead design details to China, it has endured multiple security crises, forest fires and congressional investigations into the alleged theft of computer equipment by employees. This summer, more computer disks containing classified information have disappeared, causing Peter Nanos, the lab's director, to place 19 employees on administrative leave and suspend all research activities indefinitely (see Nature 430, 387; 2004).

The suspension holds up not just work on nuclear weapons, but also an array of non-classified research ranging from genetics to computer science. Adding insult to injury, media accounts of the suspension portray the Los Alamos scientific staff as arrogant and disdainful of the bureaucratic necessities of handling classified data.

Yet the latest security crisis should not be taken at face value. The contract for running the lab, held by the University of California since 1943 , is up for competitive tender next October. Two universities from the politically well-connected state of Texas - the University of Texas and Texas A\&M - have expressed an interest in winning the contract. This might explain why Congressman Joe Barton (Republican, Texas) saw fit to visit Los Alamos as soon as the disks went missing and then called for an FBI investigation into their disappearance.

There is a growing impression that Los Alamos is not being treated fairly. It has emerged, for example, that it was not the only nuclearweapons lab to lose some classified material this summer: in late June, Sandia National Laboratories in nearby Albuquerque misplaced a disk containing such data for three weeks. No alarm bells were sounded in Washington, however, and there have been no calls to re-examine Lockheed Martin's contract to manage Sandia.
The lock-down at Los Alamos has, according to senior scientists there, had a profoundly negative impact on laboratory morale, which was already beaten down by the prospect of staff losing their valued academic affiliations with the University of California if it loses the contract. And Nanos has blasted his own staff for what he termed a "cowboy culture" at the laboratory; the tone of his public statements suggests a frightening gulf between the leader and the led.

Energy secretary Spencer Abraham, who heads the government agency that oversees Los Alamos, has also denounced the lab's employees. Linton Brooks, head of the National Nuclear Security Administration, which was set up in response to the 1999 scandal to improve management at the nuclear-weapons laboratories, has said and done nothing. And even Senator Pete Domenici (Republican, New Mexico), the most stalwart defender of Los Alamos in Congress, despairs of its future: “Today, in Washington, Los Alamos' reputation as a crown jewel of science is being eclipsed by a reputation as being both dysfunctional and untouchable," he declared in an open letter to laboratory employees on 22 July.

Any security lapse at a nuclear-weapons laboratory must be taken seriously. At Los Alamos, classified information is currently stored in more than 2,000 safes spread across its sprawling complex; it probably should be centralized along lines already used at the rival Lawrence Livermore National Laboratory in California. But without strong, credible leadership and the full cooperation of researchers, such reforms cannot be properly implemented.

It is intolerable that a national resource as important as Los Alamos should be allowed to languish for years as a political football, losing people and prestige with every bounce. It is time that Abraham, Domenici, Nanos and others sat down to decide how to give people at Los Alamos some degree of stability until the new contract is let.

\section{An opportunity lost}

No one is taking responsibility for tracking the pathological aftermath of inconclusive trials of an Alzheimer's vaccine.

$\mathrm{V}$ aluable data on patients' responses to a candidate vaccine for treating Alzheimer's disease may never be collected, now that the San Francisco arm of Elan has abandoned its trial (see page 715). The case highlights a quandary that can occur when scientifically interesting trials run out of commercial promise. The issue doesn't arise with most trials of drug therapies or medical devices, as these have no further biological influence when the trial is over. But the vaccine trial is different: long-term follow-up might shed light on the pathological consequences of Alzheimer's vaccines.

In January 2002, Elan stopped its trial of a vaccine against the amyloid- $\beta$ protein, a major constituent of the destructive brain plaques that occur in Alzheimer's, after some patients suffered brain inflammation. But many of the participants developed antibodies to amyloid- $\beta$, and these are still biologically active.

Elan reported the results of the trial, taking into account clinical data gathered until December 2002. But only one of the 28 medical centres that provided patients for the trial continues to study its patients systematically — and preliminary results suggest that the course of progress changes in the second year of immunization.

A group of patients with antibodies to amyloid- $\beta$ is a unique resource. But who should organize, and pay for, the monitoring of the group? Elan won't do it and the US Food and Drug Administration says it has no jurisdiction over what happens when a trial ends early. It will intervene only if a company is close to licensing a product, as it did, for example, to insist on the long-term monitoring of patients in gene-therapy trials. It says that placing the burden of responsibility on companies such as Elan would be a disincentive to innovation. Research funding agencies, such as the US National Institutes of Health, are also disinclined to finish off the trials of others.

Funding agencies should be more sympathetic to grant applications from researchers in participating centres who are willing to take on the onerous task of monitoring the progress of patients scattered around the world. Such work may not be particularly innovative, but it could yield important health benefits and so deserves support. 